\title{
A possible role of IL-IRN gene polymorphism in the outcome of gastrointestinal diseases associated with $H$. pylori infection
}

This article was published in the following Dove Press journal:

Clinical and Experimental Gastroenterology

17 April 2013

Number of times this article has been viewed

\author{
Rejane Mattar \\ Sergio Barbosa Marques' \\ Anibal Ferreira dos Santos' \\ Maria do Socorro \\ Monteiro' \\ Kiyoshi Iriya ${ }^{2}$ \\ Flair José Carrilho' \\ 'Department of Gastroenterology, \\ University of São Paulo School \\ of Medicine, São Paulo, SP, Brazil; \\ ${ }^{2}$ Department of Pathology, University \\ of São Paulo School of Medicine, São \\ Paulo, SP, Brazil
}

Objective: To verify whether the variable number of tandem repeat (VNTR) polymorphism in the $I L-1 R N$ gene that encodes the interleukin (IL)-1 receptor antagonist (IL-1Ra) plays a role in the outcome of gastrointestinal diseases associated with Helicobacter pylori (H. pylori) infection.

Methods: Patients with normal endoscopy $(\mathrm{n}=71)$, inflammation of the upper gastrointestinal tract only $(n=196)$, gastric ulcer $(n=28)$, duodenal ulcer $(n=76)$, and gastric cancer $(n=19)$ were studied. H. pylori infection was diagnosed by the urease test, histological examination, and polymerase chain reaction. The IL-1 receptor antagonist gene (IL- $1 R N$ intron 2 VNTR) was analyzed by polymerase chain reaction. Gastritis was scored according to the updated Sydney system of classification.

Results: $H$. pylori infection was an independent risk factor for mild (odds ratio [OR] $=5.53$ $[95 \%$ confidence interval $[\mathrm{CI}]=2.63-11.64 ; P<0.05])$, moderate $(\mathrm{OR}=83.93[95 \% \mathrm{CI}=29.7-$ 237.18; $P<0.05])$ and marked $(\mathrm{OR}=47.47[95 \% \mathrm{CI}=5.39-418.05 ; P<0.05])$ gastritis. The carriage of $I L-1 R N^{*} 2 / * 2$ had a significant protective effect of $H$. pylori infection $(\mathrm{OR}=0.31$ [95\% CI $=0.17-0.57 ; P<0.05])$. H. pylori infection was identified as an independent risk of inflammation, duodenal ulcer, and gastric ulcer. The carriage of $I L-1 R N^{*} 2 / * 2$ was an independent risk factor for gastric cancer $(\mathrm{OR}=5.81[95 \% \mathrm{CI}=1.06-31.98 ; P<0.05])$; nonetheless, the carriage of allele $2\left(I L-1 R N^{*} 2 / * 2\right.$ plus $\left.I L-1 R N^{*} \mathrm{~L} / * 2\right)$ had an independent protective effect on duodenal ulcer $(\mathrm{OR}=0.45[95 \% \mathrm{CI}=0.22-0.91 ; P<0.05])$.

Conclusions: Allele 2 of the VNTR $I L-1 R N$ polymorphism had a protective effect against duodenal ulcer and $H$. pylori infection; however, it increased the risk of gastric cancer.

Keywords: Helicobacter pylori, IL-1RN polymorphism, gastric cancer, peptic ulcer

\section{Introduction}

Helicobacter pylori ( $H$. pylori) infection is considered to be the etiological cause of chronic gastritis and peptic ulcer disease, and it has been associated with gastric cancer. ${ }^{1}$ The prevalence of $H$. pylori infection varies from $7 \%$ (Czech Republic) to $87 \%$ (South Africa); the prevalence is lower in Europe $(7 \%-33 \%)$ than in South America $(48 \%-78 \%) .^{2}$ In Brazil, there are differences in the prevalence of $H$. pylori infection depending on the local sanitary conditions. ${ }^{3}$ The poor communities show higher prevalence (from $73.3 \%-87 \%$ ) of $H$. pylori infection than those with a high standard of living, such as that in the city of São Paulo in Brazil (53\%). ${ }^{4,5}$

The lifetime risk for peptic ulcer in $H$. pylori-positive subjects increases with age and among males, and it reached $33.4 \%$ of patients in a tertiary care hospital of São Paulo. ${ }^{5}$ Other factors have been reported to play a role in the outcome of gastrointestinal
Correspondence: Rejane Mattar Hospital das Clínicas da FMUSP, Av Dr Enéas de Carvalho Aguiar 255, $9^{\circ}$ andar, sala 9159, São Paulo, SP, Brazil, 05403-000

Tel +55 II266I 6150

Fax +55 II $266 \mid 7830$

Email r.mattar@hc.fm.usp.br
(C) 2013 Mattar et al, publisher and licensee Dove Medical Press Ltd. This is an Open Access article which permits unrestricted noncommercial use, provided the original work is properly cited. 
diseases in $H$. pylori-positive subjects. Antral predominant gastritis with higher acid production is more common in the peptic ulcer and non-ulcer dyspepsia groups. ${ }^{1,5}$ Subjects with body-predominant and atrophic gastritis affecting the gastric body have low acid production, and they are at an increased risk for gastric cancer. ${ }^{1} H$. pylori virulence factors encoded by cytotoxin-associated gene (cag) pathogenicity island (a cluster of genes) have been associated with peptic ulcer disease and gastric cancer. ${ }^{6,7}$ Another issue to be considered in this interplay is that of the host genetic polymorphisms that control the inflammatory response against the bacterium, by either accentuating or attenuating the inflammatory response and affecting the disease outcome. ${ }^{8}$

Inflammatory cells in the gastric mucosa produce proinflammatory cytokines (interleukin [IL]-1 $\beta$, IL-2, IL-6, IL-8, and tumor necrosis factor [TNF]- $\alpha$ ) and anti-inflammatory cytokines (IL-4 and IL-10) in response to chronic H. pylori infection. Gastric mucosal cytokine levels may be affected by genetic polymorphisms, which result in different grades of inflammation, acid secretion, and outcome of the gastrointestinal disease. ${ }^{9}$

Among the proinflammatory cytokines, genetic polymorphisms in the $I L-1 B$ and the $I L-I R N$ genes that encode IL-1 $\beta$ and IL-1 ra (endogenous receptor antagonist of IL-1 $\beta$ ), respectively, have been widely studied in the presence of H. pylori infection, modulating the risk of hypochlorhydria, gastric atrophy, and gastric cancer. The $I L-I R N$ gene has a penta-allelic 86-bp variable number of tandem repeat (VNTR) polymorphism in intron 2 , resulting in a short allele with two repeats (IL-1RN*2) or long alleles (IL-1RN*L): allele 1 (four repeats), allele 3 (five repeats), allele 4 (three repeats), and allele 5 (six repeats). Allele 1 is more frequently found, followed by allele 2 ; the others may not be present. ${ }^{10-13}$

The presence of a single $I L-1 R N^{*} 2$ allele was associated with higher levels of IL-1 $\beta$ and two alleles $\left(I L-1 R N^{*} 2 /{ }^{*} 2\right)$ with gastric acid suppression. The increase of IL-1 $\beta$ associated with less gastric acid secretion predisposes to gastric atrophy and gastric cancer development, ${ }^{13}$ however, it may protect against duodenal ulcer because the gastric acid output is the principal cause. ${ }^{13-15}$ While the reports of studies conducted in Brazil and Portugal have shown association of $I L-1 R N^{*} 2$ allele with an increased risk of gastric cancer and chronic gastritis, ${ }^{16-18}$ other authors in Brazil failed to show this association. ${ }^{19}$ In a study conducted in Bogota, an inverse association was detected. ${ }^{20}$ Additionally, an increased risk of gastric ulcer has been reported. ${ }^{17,21}$

The levels of IL-1 $\beta$ were higher when the $I L-1 R N^{*} 2$ allele was present; ${ }^{11,13,22}$ however, in other studies, low levels of IL-1 $\beta$ were associated with the $I L-1 R N^{*} 2$ allele. ${ }^{23}$ Thus, the results concerning $I L-1 R N^{*} 2$ allele have been contradictory.

The aim of this study was to verify whether the VNTR polymorphism in the $I L-1 R N$ gene that encodes IL-1 receptor antagonist (IL-1Ra) has a role in the outcome of gastrointestinal diseases associated with $H$. pylori infection.

\section{Materials and methods}

This study was approved by the local Ethics Committee (CAPPesq n 799/04), and the patients gave written informed consent. Consecutive dyspeptic patients who underwent upper gastrointestinal endoscopy at the Endoscopy Section of Sapopemba Hospital, a primary care health center, were invited to participate in the study. Patients were selected from those who were not taking nonsteroidal anti-inflammatory drugs and proton pump inhibitors for more than 15 days. From a total of 500 consecutive endoscopies, 379 patients were included in the study. Normal endoscopy was observed in 71 patients, inflammation of the upper gastrointestinal tract only in 196 patients (esophagitis, 31; gastritis, 138; duodenitis, 27), gastric ulcer in 28 patients, duodenal ulcer in 76 patients, and diffuse type gastric cancer in eight patients. Deoxyribonucleic acid (DNA) previously extracted from the leukocytes of eleven intestinal type gastric cancer patients that were identified as leu 1 , leu 2 , leu 5 , leu 6 , leu 8 , leu 9 , leu 11, leu 12, leu 13, leu 21, and leu 22 subtypes were included because of the low number of gastric cancer patients, ${ }^{24}$ although there was no information on the $H$. pylori status. Therefore, the total number of cases that were analyzed was 390 with a mean age of $44.18 \pm 15.42$ years (69.23\% were women).

\section{DNA extraction and PCR}

DNA was extracted from gastric biopsies taken for the urease test by a salting out procedure described previously. ${ }^{25}$ The primers, IL-1RN sense 5'-CTCAGCAACACTCCTAT-3' and IL-1RN antisense 5'-TCCTGGTCTGCAGGTAA-3', described by Bioque et $\mathrm{al}^{26}$ in 1995 , were used to amplify the region within the second intron of the $I L-1 R N$ gene that encompasses the $86 \mathrm{bp} \mathrm{VNTR} \mathrm{polymorphism.} \mathrm{Genomic} \mathrm{DNA}$ $(1 \mu \mathrm{L})$ was used as a template in a reaction volume of $25 \mu \mathrm{L}$, containing $1.5 \mathrm{mM} \mathrm{MgCl}_{2}, 20 \mathrm{mM}$ Tris- $\mathrm{HCl}$ (pH 8), $50 \mathrm{mM}$ $\mathrm{KCl}, 0.2 \mathrm{mM}$ of each deoxyribonucleotide triphosphate, 10 pmol of each primer, and 2.0 U of Taq DNA polymerase (Life Technologies, Carlsbad, CA, USA). Amplification was performed as follows: at $95^{\circ} \mathrm{C}$ for 5 minutes followed by 35 cycles at $95^{\circ} \mathrm{C}$ for 30 seconds, annealing at $50^{\circ} \mathrm{C}$ for 
30 seconds and at $72^{\circ} \mathrm{C}$ for 30 seconds. The final extension at $72^{\circ} \mathrm{C}$ was performed for 5 minutes. The PCR products were visualized on a $2 \%$ agarose gel stained by ethidium bromide. The samples showing a band of $410 \mathrm{bp}$ (four repeats of the $86 \mathrm{bp}$ region) were classified as allele 1 , a band of $240 \mathrm{bp}$ (two repeats of $86 \mathrm{bp}$ region) as allele 2 , a band of $500 \mathrm{bp}$ (five repeats of $86 \mathrm{bp}$ region) as allele 3 , a band of $325 \mathrm{bp}$ (three repeats of 86 bp region) as allele 4 , and a band of 595 bp (six repeats of $86 \mathrm{bp}$ region) as allele 5. Alleles were categorized as allele 2 (the short one) and alleles 1,3, 4, and 5, the long alleles, as L. Genotype was reported as $I L-1 R N^{*} \mathrm{~L} / * \mathrm{~L}, I L-$ $1 R N^{*} \mathrm{~L} / * 2$ (allele L/allele2 heterozygote), and $I L-1 R N^{*} 2 / * 2$ (allele 2 homozygote). ${ }^{18}$

\section{$H$. pylori infection status}

Cases were considered to be $H$. pylori-positive when at least two of the following examinations were positive.

\section{PCR}

PCR for the diagnosis of $H$. pylori infection was performed according to the previously described technique, ${ }^{25}$ by using a set of primers (P1 5'-TGGCGTGTCTATTGACAGCGAGC-3', and P2 5'-CCTGCTGGGCATACTTCACCATG-3') that amplifies a 26-kDa antigen gene (Accession: M55507) present in all the strains of $H$. pylori. The conditions for amplification were as follows: $94^{\circ} \mathrm{C}$ for 5 minutes, followed by 40 cycles at $93^{\circ} \mathrm{C}$ for 1 minute, $57^{\circ} \mathrm{C}$ for 2 minutes, and $70^{\circ} \mathrm{C}$ for 2 minutes, thereby resulting in a 298 bp product stained by ethidium bromide on a $1 \%$ agarose gel. ${ }^{27}$

\section{Urease test}

The biopsy samples taken from the antrum and corpus of the stomach were inserted into the homemade urease test tubes according to the previously described technique. ${ }^{25}$ The urease test tube was examined over the next 24 hours.

\section{Histology}

Gastric biopsy samples from the antrum and corpus were fixed in $10 \%$ formalin and stained with hematoxylin and eosin, and also by Giemsa's solution (Vetec Química Fina Ltda, Duque de Caxias, RJ, Brazil) for H. pylori identification, and they were scored according to the updated Sydney system of classification and the grading of gastritis. ${ }^{28}$

\section{Statistical analysis}

Statistical analysis was performed by $\mathrm{R}$ version 2.12.1 (R Core Team, R Foundation for Statistical Computing Vienna, Austria, http://www.R-project.org). A $P$-value $<0.05$ was considered significant. In the cases that were categorized according to the endoscopic findings, age was analyzed by analysis of variance and Tukey's test, and age was included as a categorical variable, with 45 years as the cutoff value. Categorical variables in cases that were categorized according to the endoscopic findings, such as age, gender, H. pylori status, grading of chronic gastritis, and allele 2, were analyzed by Fisher's exact test. Categorical variables were subjected to simple multinomial logistic regression and multiple multinomial logistic regressions. Factors associated with $H$. pylori infection were subjected to binary logistic regression.

\section{Results}

Patients with gastric ulcer, duodenal ulcer, and gastric cancer were older than those with normal endoscopy $(P<0.05)$. Differences in gender distribution were not significant, except in the gastric cancer group. H. pylori infection was significantly more frequent in the inflammation, gastric ulcer, and duodenal ulcer groups than in the normal endoscopy group (Table 1).

The genotypic frequencies of the VNTR $I L-1 R N$ polymorphism were the following: 219 individuals $(56.2 \%)$ had $* 1 / * 1$ genotype, $103(26.4 \%)$ had $* 1 / * 2$ genotype, 55 $(14.1 \%)$ had $* 2 / * 2$ genotype, four $(1 \%)$ had $* 1 / * 3$ genotype, four $(1 \%)$ had $* 1 / * 4$ genotype, three $(0.7 \%)$ had $* 2 / * 3$ genotype, one $(0.3 \%)$ had $* 2 / * 4$ genotype, and one $(0.3 \%)$ had $* 4 / * 4$ genotype (data not shown).

The analysis of frequencies of the genotypes, considering alleles 1, 3, and 4 as long allele (L), showed that the differences among the groups and between $H$. pylori-positive and negative cases were significant (Table 2). Analysis of the frequency of allele 2 according to the histologic type of gastric cancer showed that this value was higher in the

Table I Demographic data and Helicobacter pylori status of 390 cases categorized according to the endoscopic findings

\begin{tabular}{llll}
\hline $\begin{array}{l}\text { Endoscopy } \\
(\mathbf{n})\end{array}$ & Mean age & $\begin{array}{l}\text { Male } \\
\text { gender (\%) }\end{array}$ & $\begin{array}{l}\text { Helicobacter } \\
\text { pylori-positive (\%) }\end{array}$ \\
\hline $\begin{array}{l}\text { Normal (7I) } \\
\text { Inflammation } \\
(196)\end{array}$ & $\begin{array}{l}39.0 \pm 13.0 \\
\text { I } 5.6 \pm 14.9\end{array}$ & $59(30.1)$ & $41(57.7)$ \\
$\begin{array}{l}\text { Gastric } \\
\text { ulcer (28) }\end{array}$ & $53.3 \pm 144(73.5)^{*}$ \\
$\begin{array}{l}\text { Duodenal } \\
\text { ulcer (76) }\end{array}$ & $85.4 \pm 14.8^{*}$ & $27(35.5)$ & $73(96.1)^{*}$ \\
$\begin{array}{l}\text { Gastric } \\
\text { cancer (19) }\end{array}$ & $62.4 \pm 16.7^{*}$ & $1 \mathrm{II}(57.9)^{*}$ & $7(87.5)$ of 8 cases \\
Total & 390 & $120(30.8)$ & $293(77.3)$ \\
\hline
\end{tabular}

Note: $* P<0.05$

Abbreviation: $n$, number. 
Table 2 VNTR IL-IRN polymorphism genotypes among the different groups and Helicobacter pylori infection status (\%)

\begin{tabular}{lllll}
\hline $\begin{array}{l}\text { Groups } \\
\text { (total number) }\end{array}$ & $* \mathbf{L} / * \mathbf{L}$ & $* \mathbf{2} / * \mathbf{2}$ & $* \mathbf{L} / * \mathbf{2}$ & All *2 \\
\hline Normal (7I) & $36(50.7)$ & $12(16.9)$ & $23(32.4)$ & $35(49.3)$ \\
Inflammation (196) & $108(55.1)$ & $32(16.3)$ & $56(28.6)$ & $88(44.9)$ \\
Gastric ulcer (28) & $18(64.3)$ & $\mathrm{I}(3.6)$ & $9(32.1)$ & $10(35.7)$ \\
$\begin{array}{l}\text { Duodenal ulcer (76) } \\
\text { Gastric cancer (19) }\end{array}$ & $53(69.7)$ & $5(6.6)$ & $18(23.7)$ & $23(30.3)$ \\
$\begin{array}{l}\text { Helicobacter pylori- } \\
\text { positive (293) }\end{array}$ & $171(58.4)$ & $50(10.2)$ & $92(31.4)$ & $122(41.6)$ \\
$\begin{array}{l}\text { Helicobacter pylori- } \\
\text { negative (86) }\end{array}$ & $48(55.8)$ & $23(26.7)$ & $15(17.4)$ & $38(44.2)$ \\
\hline
\end{tabular}

Notes: $P<0.05$ (by Fisher's exact test; *L/*L, $* \mathrm{~L} / * 2$ and $* 2 / * 2$ frequencies among the groups and between Helicobacter pylori-positive and negative); *L, (allele I, 3 or 4); $* 2$, allele 2 . All $* 2$, the sum of $* \mathrm{~L} / * 2$ with $* 2 / * 2$.

Abbreviations: VNTR, variable number of tandem repeat; IL, interleukin; L, long allele.

diffuse-type than in the intestinal-type, though the difference was not significant (data not shown).

All of the cases were of antral-predominant nonatrophic gastritis, except for one case of gastric ulcer that had atrophic gastritis, and therefore, the analysis was performed considering the histology of the antrum. Chronic gastritis in the disease groups was usually moderate compared to that in the normal endoscopy group $(P<0.05)$. The cases that were $H$. pylori negative frequently had no histological inflammation when compared to those with $H$. pylori infection, which usually presented with a moderate and with marked chronic gastritis $(P<0.05)$. The carriage of $I L-1 R N^{*} 2 / * 2$ showed a protective effect for mild $(\mathrm{OR}=0.43$ $[95 \% \mathrm{CI}=0.18-0.99 ; P<0.05])$ and moderate $(\mathrm{OR}=0.41$ $[95 \% \mathrm{CI}=0.19-0.88 ; P<0.05])$ gastritis by simple multinomial logistic regression. By multiple multinomial logistic regression, this estimated protective effect was not observed, and $H$. pylori infection was an independent risk factor for mild $(\mathrm{OR}=5.53[95 \% \mathrm{CI}=2.63-11.64 ; P<0.05])$, moderate $(\mathrm{OR}=83.93[95 \% \mathrm{CI}=29.7-237.18 ; P<0.05])$, and marked $(\mathrm{OR}=47.47[95 \% \mathrm{CI}=5.39-418.05 ; P<0.05])$ gastritis.

Analysis of the factors for the disease groups and for the H. pylori infection by simple logistic regression showed that H. pylori infection was a significant risk factor for inflammation, gastric ulcer, and duodenal ulcer (Table 3). The carriage of $I L-1 R N * \mathrm{~L} / * 2$ had a significant protective effect against gastric cancer $(\mathrm{OR}=0.12[95 \% \mathrm{CI}=0.01-0.93 ; P<0.05])$; however, this gene increased the risk of $H$. pylori infection $(\mathrm{OR}=2.17[95 \% \mathrm{CI}=1.18-3.99 ; P<0.05])$. In contrast, the carriage of $I L-1 R N^{*} 2 / * 2$ had a significant protective effect against $H$. pylori infection $(\mathrm{OR}=0.31[95 \% \mathrm{CI}=0.17-0.57$; $P<0.05])$ and a tendency to protect against duodenal ulcer (OR $=0.35[0.12-1.04 ; P=0.059])$. The carriage of allele 2 (the sum of $* \mathrm{~L} / * 2$ with $* 2 / * 2$ ) had a significant protective effect against duodenal ulcer $(\mathrm{OR}=0.44[95 \%$ $\mathrm{CI}=0.23-0.87 ; P<0.05]$ ) (Table 3 ).

Factors that had a tendency to be significant, or were significant by simple logistic regression for the disease groups, were analyzed by multiple multinomial logistic regression (Tables 4-6). After controlling for confounding factors, H. pylori infection was identified as an independent risk factor for inflammation, duodenal ulcer, and gastric ulcer. The carriage of $I L-1 R N * 2 / * 2$ was an independent risk factor for gastric cancer $(\mathrm{OR}=5.81[95 \% \mathrm{CI}=1.06-31.98 ; P<0.05])$; nonetheless, the carriage of allele 2 (IL- $1 \mathrm{RN} * 2 / * 2$ plus $\mathrm{IL}-1 \mathrm{RN} * \mathrm{~L} / * 2)$ had an independent protective effect against duodenal ulcer $(\mathrm{OR}=0.45[95 \% \mathrm{CI}=0.22-0.91])$.

\section{Discussion}

The acquisition of $H$. pylori infection occurs early in life, and persists lifelong; however, the infection may spontaneously be

Table 3 Adjusted odds ratio and $95 \%$ confidence intervals for the disease groups by simple logistic regression and for Helicobacter pylori infection by binary logistic regression

\begin{tabular}{|c|c|c|c|c|c|}
\hline Factor & Duodenal ulcer & Gastric ulcer & Inflammation & Gastric cancer & Helicobacter pylori \\
\hline \multirow[t]{2}{*}{ Age } & $2.01(1.03-3.92)^{*}$ & $8.17(2.89-23.08)^{*}$ & $1.73(0.98-3.06)$ & $8.33(2.47-28.08)^{*}$ & $1.36(0.83-2.22)$ \\
\hline & & & $P=0.06$ & & \\
\hline \multirow[t]{2}{*}{ Gender } & $2.05(0.98-4.33)$ & $1.49(0.55-4.05)$ & $1.60(0.84-3.06)$ & $5.16(1.75-15.15)^{*}$ & I.37 (0.79-2.38) \\
\hline & $P=0.06$ & & & & \\
\hline Helicobacter pylori & $|7.8|(5.08-62.45)^{*}$ & $129604750.98^{a}$ & $2.03(1.15-3.59)^{*}$ & $0.43(0.15-1.21)$ & \\
\hline$* \mathrm{~L} / * 2$ & $0.65(0.3 \mid-1.34)$ & $0.99(0.39-2.54)$ & $0.84(0.46-1.5)$ & $0.12(0.01-0.93)^{*}$ & $2.17(1.18-3.99)^{*}$ \\
\hline \multirow[t]{2}{*}{$* 2 / * 2$} & $0.35(0.12-1.04)$ & $0.18(0.02-1.49)$ & $0.96(0.47-1.98)$ & $\mathrm{I} .75(0.53-5.79)$ & $0.31(0.17-0.57)^{*}$ \\
\hline & $P=0.059$ & & & & \\
\hline All $* 2$ & $0.44(0.23-0.87)^{*}$ & $0.57(0.23-I .4 I)$ & $0.84(0.48-1.45)$ & $0.47(0.16-1.39)$ & $0.9(0.56-1.46)$ \\
\hline
\end{tabular}

Notes: $* P<0.05 ;{ }^{a} 95 \%$ confidence interval impossible to calculate; $*$ L, (allele I, 3, or 4 ); $* 2$, allele 2 ; All $* 2$, the sum of $* \mathrm{~L} / * 2$ and $* 2 / * 2$.

Abbreviation: L, long allele. 
Table 4 Adjusted odds ratio and 95\% confidence intervals for the disease groups by multiple multinomial logistic regression

\begin{tabular}{lllll}
\hline Factor & Duodenal ulcer & Gastric ulcer & Inflammation & Gastric cancer \\
\hline Age & $1.92(0.93-3.96)$ & $8(2.78-23.07)^{*}$ & $1.75(0.97-3.15)$ & $6.82(1.24-37.53)^{*}$ \\
Male gender & $2.03(0.93-4.45)$ & $1.72(0.6-4.95)$ & $1.6(0.84-3.06)$ & $1.4(0.25-7.88)$ \\
Helicobacter pylori & $17.64(5.03-61.83)^{*}$ & $58235168.5^{\mathrm{a}}$ & $1.97(1.12-3.48)^{*}$ & $5(0.58-43.21)$ \\
All *2 & $0.45(0.22-0.91)^{*}$ & $0.66(0.25-1.73)$ & $0.86(0.5-1.49)$ & $1.19(0.27-5.26)$ \\
\hline
\end{tabular}

Notes: $* P<0.05 ;{ }^{a} 95 \%$ confidence interval impossible to calculate. All $* 2$, $* \mathrm{~L} / * 2$ plus $* 2 / * 2$.

Abbreviation: L, long allele.

eradicated in young children. Macrolides and penicillins that are used may be associated with the loss of $H$. pylori infection in very young children; nonetheless, other children with no previous usage of antibiotics showed loss of infection..$^{29}$ In developing countries with high levels of exposure to H. pylori at a young age, some individuals never develop persistent $H$. pylori infection. It is not the high levels of exposure to H. pylori that may prevent or clear an established infection. High levels of exposure increases the risk to acquire the infection. ${ }^{30}$ Thus, host genetic factors seemed to be involved in H. pylori infection persistence.

$H$. pylori infection induces the synthesis of IL- $1 \beta$ that is important in initiating and amplifying the inflammatory response against the bacteria; ; ${ }^{9} 10,22$ however, IL-1 $\beta$ may also induce proliferation of gastric epithelial cells that could be involved in carcinogenesis and IL- $1 \beta$ inhibits gastric acid secretion. ${ }^{31}$ Low gastric acid secretion, although it may protect against duodenal ulcer, ${ }^{13-15}$ favors the corpus colonization, causing atrophic gastritis that may evolve to gastric carcinoma. ${ }^{13,15,31}$

The IL-1 receptor antagonist (IL-1 ra) competitively binds to the IL-1 receptor without activating the target cell, modulating IL- $1 \beta$ effects. The intensity of mucosal damage by the inflammatory response is mediated by a balance between these cytokines. Polymorphism in the second intron of $I L-1 R N$ (VNTR of 86-bp repeat sequence), resulting in the short allele $2\left(I L-1 R N^{*} 2\right)$, is associated with increased levels of IL-1 $13 .^{11,13,22}$

In this study, the carriage of $I L-1 R N^{*} 2 / * 2$ had a $31 \%$ lower risk of $H$. pylori infection with a higher allelic frequency in those with normal endoscopy, as in the controls of a study conducted in Bogota. ${ }^{20}$ To our knowledge, this is the first time that an association of homozygous allele 2 with a lower risk of $H$. pylori infection has been demonstrated, and this finding should be evaluated further. The association between $I L-1 R N^{*} 2$ and chronic inflammatory disorders suggested that the $I L-1 R N^{*} 2$ homozygote with increased proinflammatory immunity would combat microbial infection or colonization more efficiently. This finding was previously reported in the study of vaginal colonization by the mycoplasmas, Ureaplasma urealyticum and Mycoplasma hominis, and in HIV-infected Brazilian women who had significantly lower levels of HIV-1 RNA in their circulation than in the women with other IL-1RA genotypes. ${ }^{32}$

El Omar et $\mathrm{a}^{13}$ demonstrated an increased risk of hypochlorhydria when $I L-1 R N^{*} 2 / * 2$ was present in the homozygous state, and not in the heterozygous state. In the present study, we observed that the $I L-1 R N^{*} 2$ allele (the sum of $* 2 / * 2$ plus $* \mathrm{~L} / * 2$ ) was associated with a decreased risk of duodenal ulcer, ${ }^{14,15}$ and that the carriage of $I L-1 R N^{*} 2 / * 2$ was a risk factor for gastric cancer, as was previously described. ${ }^{13,16-18,33}$ In Portugal, this was a risk factor for developing intestinal-type gastric carcinoma; ${ }^{33}$ in this report, $I L-1 R N^{*} 2 / * 2$ was more frequently found in diffuse-type gastric carcinoma, although the number of cases was small and the difference between these subtypes was not significant. This finding should be further evaluated in a higher number of gastric cancer cases, which was one of the limitations of this study.

Despite this effect, and different from previous reports, ${ }^{18,21}$ allele 2 had no association with the grading of gastritis of the gastric antrum and with gastric ulcer. H. pylori infection was

Table 5 Adjusted odds ratio and 95\% confidence intervals for the disease groups by multiple multinomial logistic regression

\begin{tabular}{lllll}
\hline Factor & Duodenal ulcer & Gastric ulcer & Inflammation & Gastric cancer \\
\hline Age & $1.99(0.98-4.04)$ & $7.85(2.72-22.61)^{*}$ & $1.77(0.98-3.18)$ & $8.33(1.46-47.67)^{*}$ \\
Male gender & $2.01(0.94-4.32)$ & $1.72(0.6-4.95)$ & $1.6(0.84-3.06)$ & $1.36(0.24-7.8)$ \\
Helicobacter pylori & $15.96(4.55-55.95)^{*}$ & $50123474.04^{\mathrm{a}}$ & $2.01(1.12-3.63)^{*}$ & $8.85(0.89-87.64)$ \\
$* 2 / * 2$ & $0.55(0.17-1.76)$ & $0.44(0.05-3.77)$ & $1.13(0.54-2.37)$ & $5.81(1.06-31.98)^{*}$ \\
\hline
\end{tabular}

Notes: $* P<0.05 ;{ }^{a} 95 \%$ confidence interval impossible to calculate. 
Table 6 Adjusted odds ratio and 95\% confidence intervals for the disease groups by multiple multinomial logistic regression

\begin{tabular}{lllll}
\hline Factor & Duodenal ulcer & Gastric ulcer & Inflammation & Gastric cancer \\
\hline Age & $2.01(0.99-4.08)$ & $8.17(2.83-23.53)^{*}$ & $1.73(0.96-3.12)$ & $6.36(1.18-34.32)^{*}$ \\
Male gender & $2.01(0.92-4.4 I)$ & $1.72(0.6-4.95)$ & $1.6(0.84-3.06)$ & $1.35(0.24-7.57)$ \\
Helicobacter pylori & $19.49(5.56-68.33)^{*}$ & $61220949.44^{\mathrm{a}}$ & $2.08(1.15-3.74)^{*}$ & $6.23(0.71-54.9)$ \\
*L/*2 & $0.49(0.23-1.05)$ & $0.75(0.28-2.03)$ & $0.76(0.42-1.4)$ & $0.25(0.03-2.24)$ \\
& $P=0.067$ & & &
\end{tabular}

Notes: $* P<0.05 ;{ }^{a} 95 \%$ confidence interval impossible to calculate.

Abbreviation: $\mathrm{L}$, long allele.

demonstrated as an independent risk factor for histological gastritis, ${ }^{6}$ inflammation, and peptic ulcer. ${ }^{5,34,35}$

\section{Conclusions}

Allele 2 of the VNTR $I L-1 R N$ polymorphism had a protective effect against duodenal ulcer and $H$. pylori infection; however, this allele increased the risk of gastric cancer.

\section{Acknowledgments}

The authors thank Marcio Augusto Diniz for the statistical analysis and Elsevier for language editing. This study was supported in part by CAPES (Coordenação de aperfeiçoamento de nível superior).

\section{Disclosure}

The authors report no conflicts of interest in this work.

\section{References}

1. Malfertheiner P, Megraud F, O'Morain CA, et al; for European Helicobacter Study Group. Management of Helicobacter pylori infection - the Maastricht IV/ Florence Consensus Report. Gut. 2012;61(5):646-664.

2. Ford AC, Axon AT. Epidemiology of Helicobacter pylori infection and public health implications. Helicobacter. 2010;15 Suppl 1:1-6.

3. Santos IS, Boccio J, Santos AS, et al. Prevalence of Helicobacter pylori infection and associated factors among adults in Southern Brazil: a population-based cross-sectional study. BMC Public Health. 2005;5:118.

4. Rodrigues MN, Queiroz DM, Rodrigues RT, Rocha AM, Luz CR, Braga LL. Prevalence of Helicobacter pylori infection in Fortaleza, Northeastern Brazil. Rev Saúde Publica. 2005;39(5):847-849.

5. Marques SB, Mattar R, Artifon EL, Sakai P, Carrilho FJ. High prevalence of duodenal ulcer in a tertiary care hospital in the city of São Paulo, SP, Brazil. Arq Gastroenterol. 2011;48(3):171-174.

6. Mattar R, Marques SB, Monteiro Mdo S, Dos Santos AF, Iriya K, Carrilho FJ. Helicobacter pylori cag pathogenicity island genes: clinical relevance for peptic ulcer disease development in Brazil. J Med Microbiol. 2007;56(Pt 1):9-14.

7. Mattar R, Monteiro MS, Marques SB, Zilberstein B, Hashimoto CL, Carrilho FJ. Association of LEC and tnpA Helicobacter pylori genes with gastric cancer in a Brazilian population. Infect Agent Cancer. 2010;5:1.

8. Yamaoka Y. Mechanisms of disease: Helicobacter pylori virulence factors. Nat Rev Gastroenterol Hepatol. 2010;7(11):629-641.

9. Sugimoto M, Yamaoka Y, Furuta T. Influence of interleukin polymorphisms on development of gastric cancer and peptic ulcer. World $J$ Gastroenterol. 2010;16(10):1188-1200.

10. Perri F, Terracciano F, Gentile M, Merla A, Scimeca D, Zullo A. Role of interleukin polymorphisms in gastric cancer: "Pros and cons". World J Gastrointest Oncol. 2010;2(6):265-271.
11. Santtila S, Savinainen K, Hurme M. Presence of the IL-1RA allele 2 $\left(\mathrm{IL} 1 \mathrm{RN}^{*} 2\right)$ is associated with enhanced IL-1beta production in vitro. Scand J Immunol. 1998;47(3):195-198.

12. Rad R, Prinz C, Neu B, et al. Synergistic effect of Helicobacter pylori virulence factors and interleukin-1 polymorphisms for the development of severe histological changes in the gastric mucosa. J Infect Dis. 2003;188(2):272-281.

13. El-Omar EM, Carrington M, Chow WH, et al. Interleukin-1 polymorphisms associated with increased risk of gastric cancer. Nature. 2000;404(6776):398-402.

14. Garcia-Gonzales MA, Lanas A, Santolaria S, Crusius JBA, Serrano MT, Peña AS. The polymorphic IL-1B and IL-1RN genes in the aetiopathogenesis of peptic ulcer. Clin Exp Immunol. 2001;125(3):368-375.

15. Furuta T, El-Omar EM, Xiao F, Shirai N, Takashima M, Sugimura H. Interleukin 1beta polymorphisms increase risk of hypochlorhydria and atrophic gastritis and reduce risk of duodenal ulcer recurrence in Japan. Gastroenterology. 2002;123(1):92-105.

16. Oliveira JG, Duarte MC, Silva AE. IL-1ra anti-inflammatory cytokine polymorphism is associated with risk of gastric cancer and chronic gastritis in a Brazilian population, but the TNF- $\beta$ pro-inflammatory cytokine is not. Mol Biol Rep. 2012;39(7):7617-7625.

17. Melo Barbosa HP, Martins LC, Dos Santos SE, et al. Interleukin-1 and TNF-alpha polymorphisms and Helicobacter pylori in a Brazilian Amazon population. World J Gastroenterol. 2009;15(12):1465-1471.

18. Figueiredo C, Machado JC, Pharoah P, et al. Helicobacter pylori and interleukin 1 genotyping: an opportunity to identify high-risk individuals for gastric carcinoma. J Natl Cancer Inst. 2002;94(22): $1680-1687$.

19. Santos JC, Ladeira MS, Pedrazzoli J Jr, Ribeiro ML. Relationship of IL-1 and TNF- $\alpha$ polymorphisms with Helicobacter pylori in gastric diseases in a Brazilian population. Braz J Med Biol Res. 2012;45(9): 811-817.

20. Martínez T, Hernández-Suárez G, Bravo MM, et al. Association of interleukin-1 genetic polymorphism and CagA positive Helicobacter pylori with gastric cancer in Colombia. Rev Med Chil. 2011;139(10): 1313-1321.

21. Hellmig S, Titz A, Steinel S, et al. Influence of IL-1 gene cluster polymorphisms on the development of $\mathrm{H}$. pylori associated gastric ulcer. Immunol Lett. 2005;100(2):107-112.

22. Zambon CF, Basso D, Navaglia F, et al. Helicobacter pylori virulence genes and host IL-1RN and IL-1 $1 \beta$ genes interplay in favouring the development of peptic ulcer and intestinal metaplasia. Cytokine. 2002;18(5):242-251.

23. Chourasia D, Achyut BR, Tripathi S, Mittal B, Mittal RD, Ghoshal UC. Genotypic and functional roles of IL-1B and IL-1RN on the risk of gastroesophageal reflux disease: the presence of IL-1B-511*T/IL-1RN*1 (T1) haplotype may protect against the disease. Am J Gastroenterol. 2009;104(11):2704-2713.

24. Mattar R, Nonogaki S, Silva C, Alves V, Gama-Rodrigues JJ. p53 and $\mathrm{Rb}$ tumor suppressor gene alterations in gastric cancer. Rev Hosp Clin Fac Med S Paulo. 2004;59(4):172-180.

25. Mattar R, dos Santos AF, Eisig JN, et al. No correlation of babA2 with vacA and cagA genotypes of Helicobacter pylori and grading of gastritis from peptic ulcer disease patients in Brazil. Helicobacter. 2005;10(6): 601-608. 
26. Bioque G, Crusius JB, Koutroubakis I, et al. Allelic polymorphism in IL-1 beta and IL-1 receptor antagonist (IL-1Ra) genes in inflammatory bowel disease. Clin Exp Immunol. 1995;102(2):379-383.

27. Hammar M, Tyszkiewicz T, Wadström T, O’Toole PW. Rapid detection of Helicobacter pylori in gastric biopsy material by polymerase chain reaction. J Clin Microbiol. 1992;30(1):54-58.

28. Dixon MF, Genta RM, Yardley JH, Correa P. Classification and grading of gastritis. The updated Sydney System. International Workshop on the Histopathology of Gastritis, Houston 1994. Am J Surg Pathol. 1996;20(10):1161-1181.

29. Rothenbacher D, Bode G, Brenner H. Dynamics of Helicobacter pylori infection in early childhood in a high-risk group living in Germany: loss of infection higher than acquisition. Aliment Pharmacol Ther. 2002;16(9):1663-1668.

30. Kusters JG, van Vliet AH, Kuipers EJ. Pathogenesis of Helicobacter pylori Infection. Clin Microbiol Rev. 2006;19(3):449-490.
31. Basso D, Plebani M. H. pylori infection: bacterial virulence factors and cytokine gene polymorphisms as determinants of infection outcome. Crit Rev Clin Lab Sci. 2004;41(3):313-337.

32. Witkin SS, Gerber S, Ledger WJ. Influence of interleukin-1 receptor antagonist gene polymorphism on disease. Clin Infect Dis. 2002;34(2): 204-209.

33. Machado JC, Pharoah P, Sousa S, et al. Interleukin 1B and interleukin $1 \mathrm{RN}$ polymorphisms are associated with increased risk of gastric carcinoma. Gastroenterology. 2001;121(4):823-829.

34. Suzuki RB, Cola RF, Cola LT, et al. Different risk factors influence peptic ulcer disease development in a Brazilian population. World $J$ Gastroenterol. 2012;18(38):5404-5411.

35. Schöttker B, Adamu MA, Weck MN, Brenner H. Helicobacter pylori infection is strongly associated with gastric and duodenal ulcers in a large prospective study. Clin Gastroenterol Hepatol. 2012;10(5): 487-493. e1.

\section{Publish your work in this journal}

Clinical and Experimental Gastroenterology is an international, peerreviewed, open access journal, publishing all aspects of gastroenterology in the clinic and laboratory, including: Pathology, pathophysiology of gastrointestinal disease; Investigation and treatment of gastointestinal disease; Pharmacology of drugs used in the alimentary tract;
Immunology/genetics/genomics related to gastrointestinal disease. This journal is indexed on CAS. The manuscript management system is completely online and includes a very quick and fair peer-review system. Visit http://www.dovepress.com/testimonials.php to read real quotes from published authors.

Submit your manuscript here: http://www.dovepress.com/clinical-and-experimental-gastroenterology-journal 